\title{
Exploring Visitor's Responses to an Indonesia's Japanese Festival through Instagram Comment Section
}

\author{
Kania Eka Savitri ${ }^{1}$, Mohammad Mossadeq Bahri ${ }^{2}$ \\ \{kania.echo@gmail.com ${ }^{1}$, mossadeqbahri@gmail.com ${ }^{2}$ \} \\ Universitas Indonesia, Indonesia ${ }^{1,2}$
}

\begin{abstract}
This paper focused on visitors' responses to Indonesia's Japanese festival through social media. By analyzing data collected from the comment section in University of Indonesia's Japanese Study Program event namely Gelar Jepang's Instagram Feed, we found that the visitor's responses can be categorized into "pre-event excitement", "wishes for future experience" and "reviews of the event". In addition to the chance of gaining repeat visitors, these findings can also imply that there's also a chance that consumers of Japanese cultural products will come back again to consume the products in the future.
\end{abstract}

Keywords: Globalization, Cultural Diplomacy, Japanese Festival, Instagram

\section{Introduction}

Japan's cultural diplomacy to Southeast Asia countries has been going on since the rise of anti-Japanese sentiments more than four decades ago. Japan Foundation that was established in 1972 had an important role in promoting the international understanding of Japan and making an improvement of the international image of Japan through the presentation of Japanese culture overseas [1]. Cultural items, such as Japanese food, once 'authentic' to Japan, now has been made available to local people at lower prices [2]. Similar to what happened in Taiwan where local businesses did glocalization of Japanese cultural products to meet markets' demand [3], the glocalization of Japanese products has also become more common in Indonesia. However, Japanese cultural products are not only available in local markets and Japan Foundation's events, but also a Japanese festival held by local people.

This year, the Japan Foundation's official Instagram account (jf_jakarta) has shared at least ten Japanese festivals held by Japanese Studies or Senior High Schools in Indonesia. Concepted after matsuri (Japanese festival associated with Shinto ritual) or Bunkasai (a cultural festival held by most schools in Japan), some events provide a place for local tenants to sell their Japanese cultural products. Others held competition related to Japanese cultures, such as manga competition or eating Japanese food competition. Among them, the Student Association of Japanology (HIMAJA) at the University of Indonesia has been holding Gelar Jepang, one of the Japanese festivals in Indonesia, for twenty-five years since 1994. The festival provides a place for visitors to consume Japanese cultural products, gain more knowledge through workshops, watch band's performance singing Japanese songs, and a gathering place for people with the same interest.

Festivals cultural events hold important meaning for visitors. Their experience can be influenced by other visitors who make them feel a sense of belonging. They can also have a personal experience by being present or by reminiscing their experience and anticipate for a 
future experience [4]. This research explores Instagram users and Gelar Jepang visitors' experiences through Gelar Jepang Instagram Feed, and the implication related to Japan's globalization in Indonesia.

\section{Methodology}

With the current developments of technology for communication, the use of social media to interact with others has become a common fashion among people worldwide. The interaction can be found in different kinds of platforms, including Instagram. People gather there and formed an online community [5]. Data from social media becomes an important source to understand a new form of connectivity using communication devices. One of the social media platforms is the online photo and video sharing service Instagram.

Based on research on Instagram by Manikonda, Hu and Kambhampati [6], posts on Instagram tend to only receive 2.55 comments per post with only 4.7 words per comment. However, since its release in 2010, Instagram has become a popular social media platform for marketing [7] or promoting tourism destinations [8] because of its main feature in editing and sharing photos across millions of Instagram users. Instagram, like other social media platforms, can also be used as a source of research data. Using an online ethnography method. Naslund et al. [9] studied comments on YouTube videos to analyze peer support by commenters. Rageh, Melewar, and Woodside [10] also collected data from websites using the method of nethnography to analyze customer experience based on online reviews.

Therefore, the researcher in this research analyzed comments and responses from the event social media account and categorized those responses to some groups and analyzed the structure of the responses.

\subsection{Data Collection}

This research focused on the content of the comment section, the implication of the number of likes on posts and the use of the 'tag' feature on Gelar Jepang's Instagram Feed from 2014 (Gelar Jepang 20) until 2019 (Gelar Jepang 25). We choose this period because starting from Gelar Jepang 20, the staffs included performances by 'Guest Star'. Guest Star can be a Japanese singer, a band or an idol group who come and perform on the third day of Gelar Jepang. This change also caused the staff to start applying the use of entrance tickets for the third day.

We capture archival data of people who left comments on Gelar Jepang's Instagram feed and did several filtering for relevance. In the book about Nethnography by Kozinets [5], data collection is pre-existing computer-mediated communication that the researcher not directly involved in. After that, each post is categorized into 'pre-event', 'event' and 'post-event' based on the content of information whether they are related to activities before the event, during the event or after the event.

\subsection{Data Analysis}

Once the data has been collected, we examine it and search for patterns among specific details. After that, we connect it to concepts and draw a conclusion based on supportive evidence [11]. We only choose an example of comment for each category that can represent other similar comments that will fall to the same category. 


\section{Findings}

Gelar Jepang staff only started using Instagram to share information about their event in 2013. As of November 2019, the account is followed by more than 12.000 followers. Below are our findings regarding Instagram users' comments on posts in the Gelar Jepang official account.

\subsection{Pre-Event Excitement}

We found that there are expressions of excitement before the event on some posts along with brief information about the upcoming Gelar Jepang event:

\begin{tabular}{cc}
\hline Comment Example & English Translation \\
\hline Yeeeaaayyy udah ga sabar tuk dtng! & Hooray, looking forward to it! \\
\hline
\end{tabular}

The comment example is by a user who said that they cannot wait anymore to come to the event, expressing their excitement.

Beside this excitement, there are also expressions of excitement in on some posts with photos of the upcoming 'Band Featuring \& Special Performance:

\begin{tabular}{cc}
\hline Comment Example & English Translation \\
\hline Uwaaaa ada MEA! & Wow, MEA will perform on stage! \\
\hline
\end{tabular}

This expression shows a user's excitement regarding one of the performers that would come and perform on stage on stage on the third day of the upcoming Gelar Jepang event.

\subsection{Wishes for Future Experience}

We found comments expressing their wish to be able to come again on to the next Gelar Jepang event on post-event posts:

\begin{tabular}{cc}
\hline Comment Example & English Translation \\
\hline Tahun depan intinya mao kesini. gak mao & I'll surely come again next year. Whatever \\
tauu intinya tahun depan mao dateng & happens, I'll come again next year \\
\hline
\end{tabular}

The user expresses their wish to come again next year.

We also found comments expressing their request for the next Gelar Jepang's guest star and 'Band Featuring \& Special Performance':

\begin{tabular}{cc}
\hline Comment Example & English Translation \\
\hline $\begin{array}{c}\text { AKB48 sama Yuki Furukawa min sekalian } \\
\text { guest star nya. }\end{array}$ & $\begin{array}{c}\text { Dear admin, please invite AKB48 and Yuki } \\
\text { Furukawa as a guest star (on next year event). }\end{array}$ \\
\hline $\begin{array}{c}\text { Smeoga taun depan ada Obake Band } \\
\text { I hope Obake Band will perform next } \\
\text { year }\end{array}$ \\
\hline
\end{tabular}


The user expresses their request for next year's guest star.

\subsection{Reviews of the Event}

We found comments expressing positive reviews and gratitude on posts about the thirdday event and after event posts:

\begin{tabular}{cc}
\hline Comment Example & English Translation \\
\hline Arigatou gj20... Seru abis kece badai & Thank you gj20... It was really \\
acaranya... & amazing.... \\
\hline
\end{tabular}

This expression shows a user's positive review of the experience they had in Gelar Jepang. Besides the positive reviews, some users left criticism about some areas of the event:

\begin{tabular}{cc}
\hline Comment Example & English Translation \\
\hline $\begin{array}{c}\text { Panitia di parkir timur hari ini ga ada yg } \\
\text { urus parkiran mobil, pihak sponsor ampe } \\
\begin{array}{c}\text { kesulitan mau keluar karena terhalang } \\
\text { mobil lain.. tolong kordinasinya. }\end{array}\end{array}$ & $\begin{array}{c}\text { There was a lack of staff taking care of the } \\
\text { eastern parking lot which caused difficulty } \\
\text { for the sponsor people to get out because they } \\
\text { were blocked by other cars. Please sort it out. }\end{array}$ \\
\hline
\end{tabular}

There are also criticisms about the venue that was either too far or too small.

'Pre-event Excitement' shows users' enthusiasm about the festival, while their wishes for a future experience show satisfaction about the event. Therefore, they posted requests for future experience and are expecting to come again next year. Satisfied festival visitors may become repeat visitors and share their positive opinion with others. A memorable experience can also lead to an increase in a loyal visitor base [12]. While there are two kinds of reviews toward Gelar Jepang, both the positive and constructive reviews can be equally valuable as a reference for possible improvements for the next event.

Aside from the comment section, we also found that there are recent posts that got more than a thousand likes. For example, an after-event video of Gelar Jepang 25 got more than 3.500 likes and 38 comments. The number of likes and comments also show positive responses from visitors. We also found that posts about the guest star and band featuring \& special performance gained more responses from users. It shows that posts about music performers, especially guest stars from Japan, tend to gain more attention than other activities in Gelar Jepang.

Lastly, in addition to the type of comments we've explained above and questions about the event on the comment section, we also found that users tend to use 'tag' feature to tag their friend's Instagram account to inform them about the event or ask them to come together with the commenter ask them to come along. These tagging appeared on pre-event posts.

\section{Conclusions}

While annual Japanese festivals held by local people in Indonesia such as Gelar Jepang are intended as a means for Japan's globalization, they have also become a place for visitors to experience different kinds of activities, such as watching band performances, buying Japanese cultural products, etc. Exploring comments on Gelar Jepang's Instagram posts can be an alternative approach to better understand visitors' responses regarding their experience at the 
Gelar Jepang event. Based on the analysis of data collected from posts on Instagram since the first post about Gelar Jepang 20 until Gelar Jepang 25, we found that the comments can be categorized into comments that express pre-event excitement, wishes for future experience and reviews about the events. 'Pre-event excitement' is expressed on posts before the date of the event, while, wishes 'for future experience' and reviews of the event are expressed toward posts during the event or after the event on comments posted during or after the event. Positive comments can cause repeat visitors. Repeat visitors and positive experience can maintain sustainability. It can also imply that there will be repeat consumers of Japanese cultural products in the following year. Also, there's a chance that consumers of Japanese cultural products will come back to consume the products in the future.

\section{Acknowledgments}

We are grateful to University of Indonesia for the financial support to attend the conference in Semarang.

\section{References}

[1] K. Iwabuchi, "Pop-culture diplomacy in Japan: Soft power, nation branding and the question of 'international cultural exchange,"” Int. J. Cult. Policy, vol. 21, no. 4, pp. 419-432, 2015.

[2] H. Befu, "Globalization theory from the bottom up: Japan's contribution," Japanese Stud., vol. 23, no. 1, pp. 3-22, 2003.

[3] S. Huang, "Nation-branding and transnational consumption: Japan-mania and the Korean wave in Taiwan," Media, Cult. Soc., vol. 33, no. 1, pp. 3-18, 2011.

[4] K. A. McClinchey and B. A. Carmichael, "The role and meaning of place in cultural festival visitor experiences," in The tourism and leisure experience, Channel View Publications, 2010, pp. 59-78.

[5] R. V Kozinets, Netnography: Doing ethnographic research online. Sage publications, 2010.

[6] L. Manikonda, Y. Hu, and S. Kambhampati, "Analyzing user activities, demographics, social network structure and user-generated content on Instagram," arXiv Prepr. arXiv1410.8099, 2014.

[7] S. Salleh, N. H. Hashima, and J. Murphy, "Instagram marketing: a content analysis of top Malaysian restaurant brands," E-Review Tour. Res., vol. 6, pp. 1-5, 2015.

[8] M. N. Fatanti and I. W. Suyadnya, "Beyond user gaze: How Instagram creates tourism destination brand?," Procedia-Social Behav. Sci., vol. 211, pp. 1089-1095, 2015.

[9] J. A. Naslund, S. W. Grande, K. A. Aschbrenner, and G. Elwyn, "Naturally occurring peer support through social media: the experiences of individuals with severe mental illness using YouTube," PLoS One, vol. 9, no. 10, p. e110171, 2014.

[10] A. Rageh, T. C. Melewar, and A. Woodside, "Using netnography research method to reveal the underlying dimensions of the customer/tourist experience," Qual. Mark. Res. An Int. J., 2013.

[11] W. L. Neuman, Social Research Methods: Qualitative and Quantitative Approaches, vol. 8. 2014.

[12] S. T. Cole and H. C. Chancellor, "Examining the festival attributes that impact visitor experience, satisfaction and re-visit intention," J. Vacat. Mark., vol. 15, no. 4, pp. 323-333, 2009. 